\title{
RADICAL TPACIFR
}

A SOCIALIST, FEMINIST, AND ANTI-RACIST JOURNAL ON THE THEORY AND PRACTICE OF TEACHING

\section{Teaching Note Explaining Internalized Oppression Using the Film, Claudine}

by Teresa A Booker

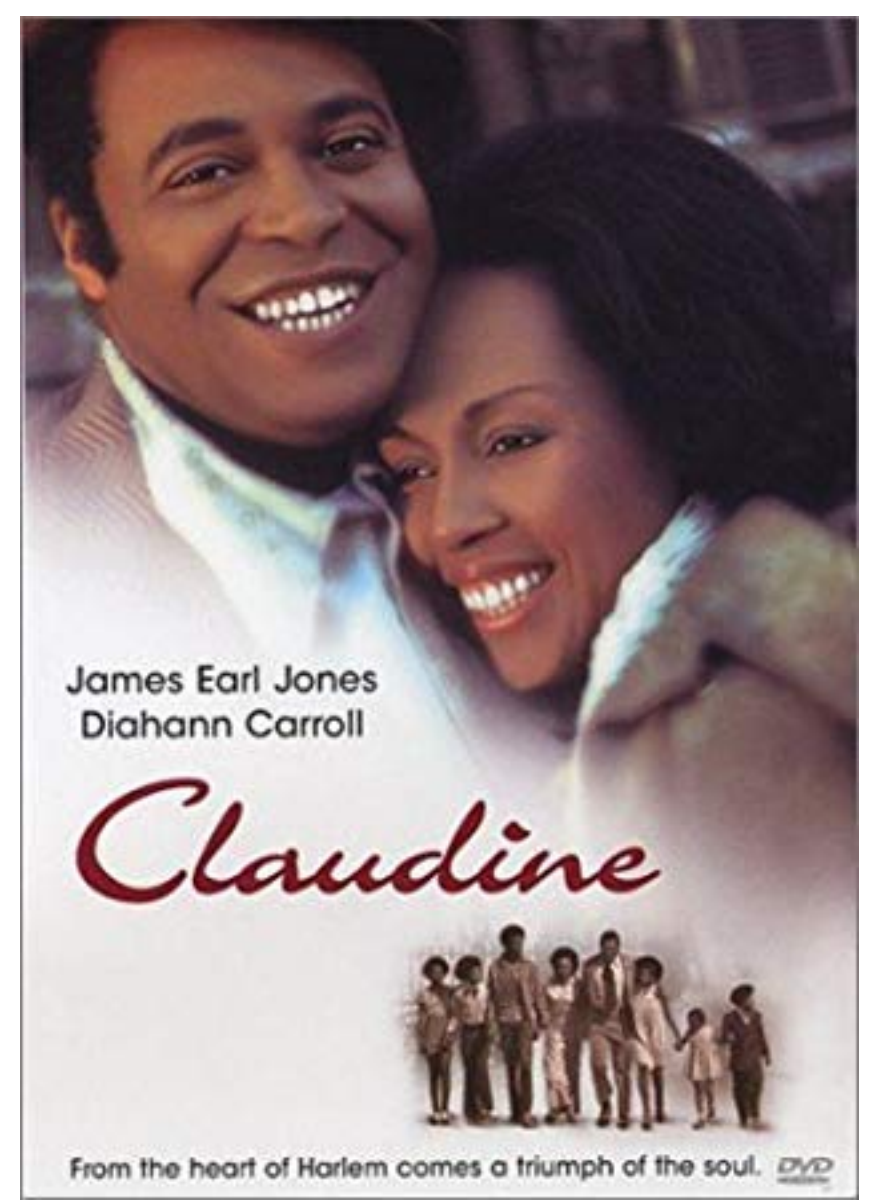

20TH CENTURY FOX 
Lester and Tina Pine's 1974 film, Claudine, is a fictitious story depicting the dating life of Claudine, a 36-year old African American mother of six who had been married twice (and "almost" twice). This film can be used to explain internalized oppression and how it might manifest itself differently even in individuals from the same families.

Racism is the discrimination against people based on skin color. Internalized racism (or internalized oppression) "denotes the various ways in which members of a targeted group come to believe the messages of oppression about themselves, their capacities, their limitations and their selfimage." (Margles \& Margles, 2010, p. 140). In classes on race and ethnicity, the classic example of internalized oppression is the Clark Doll Experiment, created by Drs. Mamie and Kenneth Clark, married African American psychologists. While investigating the racial preferences of African American children, the Clarks asked two questions of the children regarding dolls identical in every way but skin color: Which is the good/bad doll? Which doll looks most like you? More than half of the children in the study identified the white doll as good and the black doll as bad. "The Clarks[s] concluded that the children had suffered damage to their self-esteem and self-image due to segregation and the pervasive negative perception of African Americans" (Anderman and Anderman, 2009, p.147).

Claudine is set in Harlem approximately thirty-five years after the experiment. Claudine receives welfare while also supporting her family as a domestic worker for a white family in the suburbs and is paid off the books. Encouraged by her girlfriends, Claudine decides to begin dating again and agrees to go out with Rupert, a garbage man who services the house of her employer in the suburbs. When Rupert arrives at Claudine's for their first date, he is greeted by an apartment full of children: Charles, the oldest, about eighteen years old; Charlene, the oldest daughter, about sixteen; Patrice and Paul, the middle children, about fourteen and thirteen, respectively; and Francis and Lurlene, the two youngest children, approximately six and five, respectively.

Over the course of the film, the audience witnesses the budding relationship between Claudine and Rupert, as well as between Rupert and Claudine's brood. Charles is not interested in establishing a relationship with any new man in his mother's life and makes his feelings known. Not only does Charles disapprove of Claudine's dating choice, he also resents there being so many half-siblings in their small, crowded apartment. Charlene-envious of her dating mother-thinks she should be allowed to see her boyfriend, Teddy, while her mother is out with Rupert. In the absence of adult supervision, Paul socializes with unsavory characters from the neighborhood and decides to drop out of school to become a gambler on the streets. Patrice, Lurlene, and Francis warm up to Rupert relatively quickly, compared to the others. However, Francis spends a considerable amount of time pretending to be invisible after being reprimanded by his mother.

According to Margles \& Margles, "common manifestations of internalized racism include: failing to meet expectations, feeling defensive, unwanted and unwelcome; a heightened concern about the gaze and perception of others; propensities toward violence and aggression; feelings of despair and hopelessness" (2010, p.141). Examples of internalized racism are plentiful in the film, and each of Claudine's children depicts a different aspect of internalized racism. For example, a social worker regularly visits Claudine's apartment to monitor her compliance with welfare regulations. The monthly kowtowing and concealing of second-hand gifts from Rupert are too much for Charles. That, along with his feelings towards his siblings and his belief that he will never be "free" to have the same job opportunities as white men, leads him to obtain a vasectomy so that he will neither conceive children nor fail to meet the expectations of a father. Angered by Charles's rash and illconsidered act, Claudine chastises him, saying, "That's what 'Mr. Whitey' does to the black man: He cuts off his manhood-but you did it to yourself!"

Unbeknownst to Claudine, Charlene is surreptitiously dating Teddy, a character the audience never sees. Oldest daughter Charlene's willingness to have Teddy teach her "things" (like "how to hold [her] liquor") suggests that, somewhere, Charlene has accepted negative messages about her value as a person, as a young woman, and, specifically, as a young black woman. Her self-loathing and defensiveness about her boyfriend manifest themselves during an argument with her mother when Charlene yells, "I'm nothing! That's what I am. I don't know nothing. I don't have nothing...I'm nothing!"

Rupert saves Claudine's third son, Paul, from the streets by intervening during Paul's dice game. While watching Paul play dice with street gamblers, Rupert notices Paul's ability to perform complex mental arithmetic with little effort and convinces him to go back to school. Although Paul's reasons for dropping out are never stated (and nothing about his speech, dress, or habits suggests that he aspires to be or acts white), one can assume that his talent sparks accusations from his classmates. So, with regards to the doll experiment, since Paul can't be both "good" (in this case, at mathematics, a perceived "white area" of activity) and black (meaning behaving in a way that maintains his acceptance by his community), he is willing to accept society's stigma to fit in with neighborhood expectations. Paul must make a choice between the lesser of two stigmas/expectation paths: one of working the streets (causing him the least amount of stigma from those he cares about most, while simultaneously not conflicting with their expectations) and the other of appearing to meet/exceed the low expectations of his teachers (while simultaneously not conflicting with their expectations, either). Street hustlers are expected to be smart and good with numbers. So, Paul literally did the math and realized that math skills were better rewarded on the street.

Although Francis is young (and his pretense of invisibility little more than a childish exploit), his feelings of despair only appear after he is chastised by Claudine. Moreover, when he does speak-as evidenced by his description of his art-he longs for a family with a "mommy and a daddy." So, not only does he feel less valuable as a family member when his mother takes his sister Lurlene's side over his, but Francis also appears to have accepted 
some negative message that his family is less valuable because it is incomplete.

Internalized oppression is not automatic. The strong, the mature, and the properly socialized can avoid it because people can choose to not buy into negative propaganda and, ultimately, implement a self-fulfilling prophesy for themselves. It is ultimately up to them. While on their first date, Claudine and Rupert discuss their marital histories and number of offspring. As they talk, they offend one another with their questions. As they offend, each sarcastically appropriates the racial stereotypes of African Americans onto themselves. When asked why she has so many children, Claudine says that she "grinds them out" just to get a few bucks, per child, in welfare. When asked why he doesn't see his children, Rupert says, "You know us heartless 'studs' with no feelings..." The sarcastic tone of the conversation reveals that nothing they say is true. Moreover, it is obvious that neither believes the propaganda of the dominant group. Their use of those stereotypes-even between themselves - illustrates that they are aware of the negativity directed towards them even if it does not apply directly to them.

When asked what daily messages might feed into characters' internalized oppression, students hypothesize that Charlene hears that she is less valued if she doesn't have a boyfriend, that she is not a "real" girlfriend unless she has sex, or that it is foolish for unattractive girls like her to hold on to their virginity because they are not guaranteed any man, down the road. They argue that Charles is told by Claudine that his comments/opinions are not valued, he believes he can't be a "real man" without equal access to jobs, and he witnesses that his chivalrous desire to defend his mother's honor can be undermined if Rupert, a man more than twice his weight, allows himself to be hit by a child (Charles). In an age of Black Lives Matter-which is the lens through which these students see the world- it is easy for them to conceive of Charles's desire not to bring children into the world and Francis's need to be invisible.

Students indicated that they enjoyed both the film and its connection to the theme, internalized oppression. Some report that they have told their parents about the film while others say, when they see me in the halls, that they either still remember the film or will be registering for a future course of mine because they remember this specific film from a past class. Claudine provides a realistic case study that supports examination of internalized oppression.

\section{References}

Clark, Kenneth Bancroft 1914-2005. (2009). In E. M. Anderman \& L. H. Anderman (Eds.), Psychology of Classroom Learning: An Encyclopedia (Vol. 1, pp. 146147). Detroit, MI: Macmillan Reference USA. Retrieved from

http://link.galegroup.com.ez.lib.jjay.cuny.edu/apps/do c/CX3027800054/GVRL?u=cuny_johnjay\&sid=GVRL\&x id $=930 \mathrm{~d} 6691$

Margles, S., \& Margles, M. (2010, Spring). Inverting racism's distortions. Our Schools, our Selves, 19, 137-149. Retrieved from http://ez.lib.jjay.cuny.edu/login?url=https://searchproquestcom.ez.lib.jjay.cuny.edu/docview/872774698?accounti $\mathrm{d}=11724$ (cc) EY-NC-ND

ULLS D-Serbe
This work is licensed under a Creative Commons Attribution-Noncommercial-No Derivative Works 3.0 United States License.

This journal is published by the University Library System of the University of Pittsburgh as part of its D-Scribe Digital Publishing Program, and is cosponsored by the University of Pittsburgh Press.

RADICALTEACHER 